\title{
The emerging era of Big Data Analytics
}

\author{
Amir Hussain ${ }^{1 *}$ and Asim Roy ${ }^{2}$
}

\footnotetext{
* Correspondence: ahu@cs.stir.ac.uk ${ }^{1}$ Division of Computing Science \& Maths, School of Natural Sciences, University of Stirling, Stirling FK9 4LA, Scotland, UK

Full list of author information is available at the end of the article
}

\begin{abstract}
We would like to welcome you to Big Data Analytics, a pioneering multi-disciplinary open access and peer-reviewed journal, which welcomes cutting-edge articles describing biologically-inspired computational, theoretical, experimental, and integrative accounts of all aspects of big data science analytics. This editorial outlines the aims, scope, and future vision of the journal.
\end{abstract}

\section{Advisory and Editorial Boards}

The journal is run by the founding Editor-in-Chief, a Senior Editor, three Section Editors, and a distinguished Editorial Board [1]. A world-leading Advisory Board provides strategic advice regarding the journal's future directions.

\section{Aims and scope}

Big Data Analytics welcomes cutting-edge articles describing original theoretical and applied work involving biologically-inspired computational accounts of all aspects of big data science analytics. Spanning the life and medical sciences, social sciences, engineering, physical, and mathematical sciences, Big Data Analytics aims to provide a platform for the dissemination of research, current practices, and future trends in the emerging discipline of big data analytics.

Big Data Analytics invites high-quality original research articles and timely reviews on current developments in the field, covering all aspects of big data analytics, including, but not limited to the following topics:

- algorithmic, theoretical, experimental, computational and integrative approaches

- implementations and platforms

- applications in diverse scientific domains.

\section{Future vision}

Part of our vision for this journal is to underline the importance of ensuring a flexible and open-ended definition of big data, one that can change with time, in order to meet the increasingly wide expectations of our multi-disciplinary audience. We believe such flexibility is important, as the past is an indicator of the future and the size and scale of problems is only expected to increase.

Analytics will play an increasingly central role in making sense of big data and exploiting its value, drawing on powerful human cognitive capabilities such as learning, pattern recognition and classification in real-world noisy and imprecise environments.

(C) 2016 The Author(s). Open Access This article is distributed under the terms of the Creative Commons Attribution 4.0 International License (http://creativecommons.org/licenses/by/4.0/), which permits unrestricted use, distribution, and reproduction in any medium, provided you give appropriate credit to the original author(s) and the source, provide a link to the Creative Commons license, and indicate if changes were made. The Creative Commons Public Domain Dedication waiver (http://creativecommons.org/ publicdomain/zero/1.0/) applies to the data made available in this article, unless otherwise stated. 
This will, in turn, aid the mining of heterogeneous data sets for revealing hidden knowledge, patterns, and relationships. The human brain's neocortex for instance, has been described as the world's most advanced, associative, and predictive big data engine [2].

However, learning from big data will also require the development of novel types of algorithms and architectures. Most conventional machine-learning algorithms cannot easily scale up to big data, hence cannot cope with the associated challenges of high dimensionality, velocity, and variety. Next-generation, scalable, cognitive, and neural technologies are expected to become significant components of big data analytics platforms, and our pioneering open access journal aims to advance this collaboration. In the long term, we hope this journal will promote new advances and cross-disciplinary research directions in the development of a range of efficient and innovative algorithmic, theoretical, experimental, computational and integrative approaches to analyse big data, facilitating solutions for diverse complex real-world problems.

Authors' contributions

$\mathrm{AH}$ and $\mathrm{AR}$ drafted the manuscript. Both authors read and approved the final manuscript.

Competing interests

The authors declare that they have no competing interests.

Author details

'Division of Computing Science \& Maths, School of Natural Sciences, University of Stirling, Stirling FK9 4LA, Scotland, UK. ${ }^{2}$ WPC Information Systems, Arizona State University, Tempe Campus, Tempe, Arizona, USA.

Received: 12 April 2016 Accepted: 24 May 2016

Published online: 01 July 2016

References

1. Editorial Board. In: Big Data Analytics. 2016. http://bdataanalytics.biomedcentral.com/about/editorial-board. Accessed 29 Mar 2016.

2. Oberlin S. Machine Learning, Cognition, and Big Data. CA Technologies. 2012. http://www.ca.com/us/ /media/files/ articles/ca-technology-exchange/machine-learning-cognition-and-big-data-oberlin.aspx. Accessed 21 Oct 2015.

Submit your next manuscript to BioMed Central and we will help you at every step:

- We accept pre-submission inquiries

- Our selector tool helps you to find the most relevant journal

- We provide round the clock customer support

- Convenient online submission

- Thorough peer review

- Inclusion in PubMed and all major indexing services

- Maximum visibility for your research

Submit your manuscript at www.biomedcentral.com/submit 